\title{
Hyperuricemia and Associated Factors during Arterial Hypertension in Brazzaville (Congo)
}

\author{
Stéphane Méo Ikama1 ${ }^{*}$, Amorce Rolles Matingou', Jospin Makani1, Norbert Lamini Nsounda², \\ Solange Flore Mongo-Ngamami1, Bertrand Fikhaem Ellenga-Mbolla1, Louis Igor Ondze-Kafata ${ }^{1}$, \\ Thierry Raoul Gombet ${ }^{1}$, Suzy Gisèle Kimbally-Kaky ${ }^{1}$
}

${ }^{1}$ Department of Cardiology, Brazzaville University Hospital Center, Brazzaville, Congo

${ }^{2}$ Department of Rhumatolology, Brazzaville University Hospital Center, Brazzaville, Congo

Email: *stephane.mikama@gmail.com

How to cite this paper: Ikama, S.M., Matingou, A.R., Makani, J., Nsounda, N.L., Mongo-Ngamami, S.F., Ellenga-Mbolla, B.F., Ondze-Kafata, L.I., Gombet, T.R. and Kimbally-Kaky, S.G. (2019) Hyperuricemia and Associated Factors during Arterial Hypertension in Brazzaville (Congo). World Journal of Cardiovascular Diseases, 9, 236-244. https://doi.org/10.4236/wjcd.2019.93021

Received: February 5, 2019

Accepted: March 24, 2019

Published: March 27, 2019

Copyright $\odot 2019$ by author(s) and Scientific Research Publishing Inc. This work is licensed under the Creative Commons Attribution International License (CC BY 4.0).

http://creativecommons.org/licenses/by/4.0/

(c) (i) Open Access

\begin{abstract}
A longitudinal analytical and comparative study including outpatients was carried between June $1^{\text {st }}$ and December $31^{\text {st }} 2017$. The objectives were to determine the hyperuricemia frequency during arterial hypertension, to identify associated factors, and to evaluate its impact on the blood pressure control. We have included, hypertensive patients having a minimum blood test including at least an uricemia. They were divided into two groups according to whether they have presented a hyperuricemia (HU) or a normouricemia (NU). Among these 202 patients included, 61 (30.2\%) presented a hyperuricemia. The mean age in $\mathrm{HU}$ group was $54.6 \pm 11.6$ years vs $53.6 \pm 11$ years for NU group $(\mathrm{p}=0.573)$. Following cardiovascular risk factors were more found in the HU group than NU group: overweight/obesity ( $68.8 \%$ vs $46.1 \%$; $p=0.003)$, metabolic syndrome $(42.6 \%$ vs $39 \% ; \mathrm{p}=0.021)$. Diuretics were used in $72.1 \%$ of patients in HU group vs $47.5 \%$ in NU group ( $\mathrm{p}=0.002)$. Bitherapy was used in $56 \%$ of the patients of HU group vs $69 \%$ in the NU group ( $\mathrm{p}=0.295)$, and the quadritherapy in $8 \%$ and $1 \%$ of the patients respectively $(\mathrm{p}=0.049)$. Blood pressure was not controlled in $68.8 \%$ of HU group vs $48.9 \%$ in the NU group $(p=0.014)$. In multivariate analysis after logistic regression, factors associated with hyperuricemia were: glucose intolerance or diabetes $(\mathrm{p}=$ 0.004; $\mathrm{OR}=1.35)$ and uncontrolled blood pressure $(\mathrm{p}=0.006$; $\mathrm{OR}=2.51)$. This preliminary study showed that hyperuricemia is commonly found in hypertensive patients and has negative impact on blood pressure control.
\end{abstract}

\section{Keywords}

Hypertension, Hyperuricemia, Frequency, Blood Pressure Control, Congo

\section{Introduction}

Arterial hypertension (HTN) is a major public health problem worldwide [1] 
[2]. Hyperuricemia is increasingly pointed out in the occurrence of cardiovascular complications [3] [4] [5]. The relation between hyperuricemia and HTN has been known for several years [6] [7] [8] [9]. However, the question of the responsibility for the one on the other remains unsolved. Blood pressure control and the reduction of the global cardiovascular risk are the main objectives of the HTN management. Studies carried out in Congo showed a poor blood pressure control due to a precarious socio-economic condition and an insufficient therapeutic education [10] [11]. Also, the accountability of the hyperuricemia was not studied. It is in this context that we conducted this study. The objectives are to determine the hyperuricemia prevalence during the HTN, to identify associated factors, and to evaluate its impact on blood pressure control.

\section{Patients and Methods}

A longitudinal study with a prospective data collection, analytical and comparative was carried in cardiology department of outpatient at the Brazzaville University Hospital Center, from June 1 to December 31st 2017. Were included, hypertensive patients recently diagnosed or known hypertensive patients on treatment, having blood tests done including uricemia, complete blood count, fasting blood sugar, renal function test (creatinine and glomerular filtration rate were estimated by using the MDRD equation; considered to be lowered if GFR < $60 \mathrm{ml} / \mathrm{min}$ ), cholesterol and its fractions, triglycerides, and a morphological assessment including electrocardiogram, echocardiography, and an ambulatory blood pressure monitoring (ABPM) if necessary. Hyperuricemia was defined by an uric acid rate $>70 \mathrm{mg} / \mathrm{l}(420 \mu \mathrm{mol} / \mathrm{l})$ for man and $>60 \mathrm{mg} / \mathrm{l}(385 \mu \mathrm{mol} / \mathrm{l})$ for woman. Patients were thus subdivided into two groups according to whether they presented an hyperuricemia (HU) or a normouricemia (NU).The dosage of the uricemia was made at the laboratory of biochemistry of the Brazzaville UniversityHospital, using spectrophotometric method on device brand name KENZA MAX Bio ChemisTry, manufactured by BIOLABO.The sociodemographic, clinical and paraclinical data of 202 patients were collected and analyzed.Thus, several variables have been studied, such as:

- sociodemographic data: age, gender, socio-economic level defined according to ECOM investigation [12] into low, medium and high;

- associated cardiovascular risk factors: diabetes, overweight/obesity, tobacco use, dyslipidemia, sedentariness, metabolic syndrome;

- predisposing factors to hyperuricemia (neoplasia, chemotherapy, alcohol intake), and its complications (gout, tophus);

- data related to the HTN: levels of blood pressure, drug classes and therapeutic protocols used, the threshold of blood pressure control was defined by a blood pressure $<140 / 90 \mathrm{mmHg}$ during a clinical measurement and/or $<130 / 80 \mathrm{mmHg}$ during an ambulatory blood pressure monitoring (ABPM). 


\subsection{Definition of the Concepts}

- Hypertension was defined by a blood pressure $>140 / 90 \mathrm{mmHg}$ on the average of three measurements in a medical office or a normal blood pressure for patients on antihypertensive treatment, or blood pressure greater than 135/85 mmHg during daytime of the ABPM.

- Diabetes was defined by a fasting blood sugar $>1.26 \mathrm{~g} / \mathrm{l}$ twice or a non-fasting blood sugar $>2 \mathrm{~g} / \mathrm{l}$ or diabetic patient on treatment.

- Glucose intolerance was defined as a fasting blood sugar between 1.10 and $1.26 \mathrm{~g} / \mathrm{l}$.

- The dyslipidemia was defined as a hypoHDLemia $<0.50 \mathrm{~g} / \mathrm{l}$ and/or a hypertriglyceridemia $>1.65 \mathrm{~g} / \mathrm{l}$ and/or a hyperLDLemia $>1.40 \mathrm{~g} / \mathrm{l}$.

- Obesity corresponded to a body mass index (BMI) $>30 \mathrm{~kg} / \mathrm{m}^{2}$ and/or overweight with a BMI between 25 and $29.9 \mathrm{~kg} / \mathrm{m}^{2}$.

- Abdominal obesity was defined by a waist circumference $>80 \mathrm{~cm}$ for woman and $>94 \mathrm{~cm}$ for man.

- Metabolic syndrome was defined according to the criteria of the International Diabetes Federation (IDF) [13] by the association of at least three of the five following items: HTN, glucose intolerance, abdominal obesity, a hypoHDLemia, hypertriglyceridemia.

- Renal failure was defined as a glomerular filtration rate (GFR) less than 60 $\mathrm{mL} / \mathrm{min}$ using MDRD formula.

\subsection{Statistical Analysis}

The software SPSS 16.0 and Stata 12.0 were used to make the statistical analysis. The test of Wald was used to make the multivariate analysis by logistic regression. The significance level was $\mathrm{p}<0.05$.

\section{Results}

Among these 202 hypertensive patients included in the study, 61 (30.2\%) presenting hyperuricemia, with an average uric acid rate of $84.9 \pm 23.0 \mathrm{mg} / \mathrm{l}$ in $\mathrm{HU}$ group versus $52.3 \pm 32.9 \mathrm{mg} / \mathrm{l}$ in the NU group ( $<0.001$ ). In the group, there were 104 men (51.5\%) and 98 women (48.5\%), average age of $53.9 \pm 11.2$ years old (range: $32-89$ years), without statistical difference between both groups (HU:54.6 \pm 11.6 years old vs NU: $53.6 \pm 11$ years old; $\mathrm{p}=0.573$ ). Thirty four patients $(16.8 \%)$ had a low socio-economic status, 131 patients $(64.8 \%)$ had a medium socio-economic status, and 37 patients (18.3\%) had a high socio-economic status, without statistical difference between the both groups. The HTN, known in 147 patients (72.7\%), had an average duration of $8.3 \pm 6.9$ years in HU group versus $6.9 \pm 6.5$ years in the NU group $(p=0.246)$. Associated cardiovascular risk factors such as overweight/obesity and the metabolic syndrome were more frequently found in HU group than in the NU group (68.8\% vs $46.1 \%$; $p=0.003$ and $42.6 \%$ vs $39 \% ; \mathrm{p}=0.021$ respectively). We did not found any case of arthritis or tophus.Main characteristics of the population studied are represented in $\mathrm{Ta}$ ble 1, and the biological parameters of the patients in Table 2. 
Table 1. Characteristics of the studied population.

\begin{tabular}{|c|c|c|c|}
\hline & $\begin{array}{c}\text { HU group } \\
(\mathrm{n}=61)\end{array}$ & $\begin{array}{l}\text { NU group } \\
(\mathrm{n}=141)\end{array}$ & $\mathrm{p}$ \\
\hline Known hypertension, $n(\%)$ & $47(77.0)$ & $100(70.9)$ & 0.467 \\
\hline \multicolumn{4}{|c|}{ Associated cardiovascular risk factors, $n(\%)$} \\
\hline - diabetes & $8(13.1)$ & $13(9.2)$ & 0.219 \\
\hline - glucose intolerance & $7(11.5)$ & $8(5.7)$ & 0.071 \\
\hline - dyslipidemia & $28(45.9)$ & $60(44.7)$ & 0.873 \\
\hline - overweight/obesity & $42(68.8)$ & $65(46.1)$ & 0.003 \\
\hline - abdominal obesity & $38(62.3)$ & $96(68.1)$ & 0.424 \\
\hline - metabolic syndrome & $26(42.6)$ & $55(39.0)$ & 0.021 \\
\hline - tobacco use & $4(6.5)$ & $9(6.4)$ & 1 \\
\hline \multicolumn{4}{|c|}{ Factors predisposing with the hyperuricemia, $n(\%)$} \\
\hline - neoplasia & $2(3.3)$ & $0(0)$ & 0.031 \\
\hline - chemotherapy & $1(0.7)$ & $0(0)$ & 0.127 \\
\hline - alcohol consumption & $17(27.8)$ & $51(36.2)$ & 0.325 \\
\hline \multicolumn{4}{|l|}{ Complications of hypertension, n (\%) } \\
\hline - left ventricular hypertrophy & $12(19.7)$ & $16(11.3)$ & 0.181 \\
\hline - heart failure & $19(31.0)$ & $35(25.0)$ & 0.131 \\
\hline - stroke & $5(8.0)$ & $44(31.0)$ & 0.071 \\
\hline - renal insufficiency & $33(54.0)$ & $62(44.0)$ & 0.098 \\
\hline \multicolumn{4}{|l|}{ Therapeutic classes used, $n(\%)$} \\
\hline - thiazides & $44(72.1)$ & $67(47.5)$ & 0.002 \\
\hline - calcium antagonists & $42(68.8)$ & $96(68.1)$ & 1 \\
\hline - ACEi/ARBs & $40(65.6)$ & $89(63.1)$ & 0.862 \\
\hline - betablockers & $16(26.2)$ & $21(14.9)$ & 0.086 \\
\hline - spironolactone & $4(6.6)$ & $3(2.1)$ & 0.092 \\
\hline Controlled hypertension, $n(\%)$ & $19(31.2)$ & $72(51.1)$ & 0.01 \\
\hline
\end{tabular}

ACEi: angiotensin-converting enzyme inhibitors; ARBs: angiotensin receptor blockers.

The average blood pressure of the patients at inclusion was of $164.8 \pm 23.1$ vs $164.3 \pm 22.7 \mathrm{mmHg}$ for the systolic $(\mathrm{p}=0.886)$, and $96.1 \pm 13.4$ vs $98.0 \pm 12.5$ $\mathrm{mmHg}$ for the diastolic $(\mathrm{p}=0.334)$, respectively in $\mathrm{HU}$ and $\mathrm{NU}$ groups. Table 3 gives the evolution of the blood pressure levels at the medical office and ABPM.

The main drug classes used are shown in Table 1.

The antihypertensive protocol used were monotherapy ( $8 \%$ vs $12 \% ; \mathrm{p}=0.8$ ), biotherapy ( $56 \%$ vs $69 \%$; $\mathrm{p}=0.3$ ), tritherapy ( $28 \%$ vs $23 \%$; $\mathrm{p}=0.5$ ), quadritherapy and more ( $8 \%$ vs $1 \% ; \mathrm{p}=0.04)$ respectively in $\mathrm{HU}$ and $\mathrm{NU}$ groups. Five patients have received allopurinolas treatment.

HTN was controlled among 19 patients of HU group (31.2\%) versus 72 patients of the NU group (51.1\%), with a significant statistical difference $(p=0.01)$. 
Table 2. Biological parameters of the patients.

\begin{tabular}{cccc}
\hline & $\begin{array}{c}\text { HU group } \\
\text { mean } \pm \text { SD }\end{array}$ & $\begin{array}{c}\text { NU group } \\
\text { mean } \pm \text { SD }\end{array}$ & p \\
\hline Uricemia $(\mathrm{mg} / \mathrm{l})$ & $84.9 \pm 23.0$ & $52.3 \pm 32.9$ & $<0.001$ \\
Creatininemia $(\mathrm{mg} / \mathrm{l})$ & $11.6 \pm 12.6$ & $11.3 \pm 4.2$ & 0.777 \\
GFR $(\mathrm{ml} / \mathrm{min})$ & $84.7 \pm 25.3$ & $89.0 \pm 20.2$ & 0.715 \\
Glycemia $(\mathrm{g} / \mathrm{l})$ & $1.0 \pm 0.3$ & $1.1 \pm 0.8$ & 0.459 \\
Total cholesterol $(\mathrm{g} / \mathrm{l})$ & $2.0 \pm 0.4$ & $2 \pm 0.6$ & 0.859 \\
HDL cholesterol $(\mathrm{g} / \mathrm{l})$ & $0.7 \pm 0.4$ & $0.6 \pm 0.2$ & 0.332 \\
LDL cholesterol $(\mathrm{g} / \mathrm{l})$ & $1.2 \pm 0.5$ & $1.2 \pm 0.5$ & 0.691 \\
Triglycerides $(\mathrm{g} / \mathrm{l})$ & $1.0 \pm 0.4$ & $0.91 \pm 0.42$ & 0.183 \\
Haemoglobin $(\mathrm{g} / \mathrm{dl})$ & $12.4 \pm 1.2$ & $13.0 \pm 6.4$ & 0.282 \\
\hline
\end{tabular}

GFR: glomerular filtration rate; SD: standard deviation.

Table 3. Evolution of the blood pressure level ( $\mathrm{mmHg})$ in private clinic and ABPM.

\begin{tabular}{cccc}
\hline & $\begin{array}{c}\text { HU group } \\
\text { mean } \pm \text { SD }\end{array}$ & $\begin{array}{c}\text { NU group } \\
\text { mean } \pm \text { SD }\end{array}$ & p \\
\hline SBP M0 & $164.8 \pm 23.1$ & $164.3 \pm 22.7$ & 0.886 \\
DBP M0 & $96.1 \pm 13.4$ & $98.0 \pm 12.5$ & 0.334 \\
SBP M3 & $150.2 \pm 22.8$ & $147.9 \pm 16.9$ & 0.496 \\
DBP M3 & $89.1 \pm 13.4$ & $89.6 \pm 10.3$ & 0.773 \\
SBP M6 & $140.4 \pm 15.1$ & $138.4 \pm 14.4$ & 0.374 \\
DBP M6 & $85.2 \pm 12.1$ & $84.1 \pm 11.2$ & 0.538 \\
SBP in 24 h ABPMM6 & $138.6 \pm 13.2$ & $134.9 \pm 15.6$ & 0.321 \\
DBP in 24 h ABPMM6 & $86.8 \pm 8.7$ & $84.8 \pm 10.6$ & 0.411
\end{tabular}

ABPM: ambulatory blood pressure monitoring; DBP: diastolic blood pressure; M0: in inclusion; M3: in the third month; M6: in the sixth month; SBP: systolic blood pressure; SD: standard deviation.

The multivariate analysis after logistic regression found out that among the various analyzed factors, only glucose intolerance/diabetes and uncontrolled blood pressure were associated with the hyperuricemia. The results of this logistic regression are presented in Table 4.

\section{Discussion}

The prevalence of the hyperuricemia was $30.2 \%$ in our study, comparable with those noted in Cameroun [14] and Nepal [15], respectively of $31.8 \%$ and $28.8 \%$, thus raising strong relationship between the HTN and the hyperuricemia.This fact is so obvious that the uricemia is listed among the WHO minimum assessment for the HTN. In the general population, this prevalence is much lower, lies between $14 \%-25 \%$ according to series' [16] [17] [18]. In the hypertensive population, the considerable use of diuretic in the management of the HTN contributes to maintain this reality [7] [19] [20]. This fact was pointed out in our series where thiazides diuretics were used in $72 \%$ of patients with hyperuricemia against $67 \%$ of patients with normal uric acid rate. Although certain factors such 
Table 4. Logistic regression of the hyperuricemia associated factors.

\begin{tabular}{ccccc}
\hline & Coefficient & OR & CI (95\%) & p \\
\hline Overweight/obesity & 0.013 & 1.13 & $0.34-1.93$ & 0.799 \\
Glucose intolerance/diabetes & 1.40 & 1.35 & $1.30-1.39$ & 0.043 \\
Metabolic syndrome & 0.87 & 0.42 & $0.22-0.61$ & 0.194 \\
Renalin sufficiency & 0.90 & 2.24 & $1.05-3.44$ & 0.198 \\
Neoplasy & 2.10 & 1.35 & $0.35-2.35$ & 0.999 \\
Thiazides & 0.99 & 2.56 & $2.46-2.64$ & 0.090 \\
Quadritherapy and more & 2.13 & 8.43 & $8.34-8.50$ & 0.082 \\
Uncontrolled hypertension & 0.88 & 2.51 & $2.50-2.51$ & 0.006 \\
\hline
\end{tabular}

as the existence of a neoplasia, chemotherapy, and the regular alcohol intake were identified as predisposing factors to the occurrence of a hyperuricemia, some studies pointed out a link between the hyperuricemia and some factors of cardiovascular risk. Such is the case of overweight/obesity [21] [22] [23] [24], glucose intolerance/diabetes [24] [26], and metabolic syndrome [16] [20] [23] [25] [27]. This association would be the fact of a food rich in purins, an insulin-resistance and an hyperinsulinism in obese subject [23]. These various factors of cardiovascular risk were found in our study in variable proportions, and only glucose intolerance/diabetes was strongly associated to the hyperuricemia in multivariate analysis.

Blood pressure control remains a real problem in medical practice, because approximately $50 \%$ of the hypertensive patients do not achieve the therapeutic goal according to a great cohort study involving twelve European countries [28]. In sub-Saharan Africa, the report is even more alarming, with less than $10 \%$ of the hypertensive patients achieving the blood pressure goal [29]. The factors in question are classically related to a noncompliance to treatment [10] [11]. However, in subjects with hyperuricemia, the achievement of this objective is much more difficult because this metabolic disorder is known to be a powerful factor of uncontrolled blood pressure [9]. As pointed out by Zhu et al. in China [27], the intensification of antihypertensive treatment was more significant in the group of the patients having an hyperuricemia. In the same way, the reduction of the blood pressure level under antihypertensive treatment was marked in this group. This fact was reported in an European multicentric study [30] and in Asia [27] [31] [32] [33]. Indeed, the arterial rigidity more marked in subjects of $\mathrm{HU}$ group could be the most plausible explanation in spite of an adequate treatment [30]. Thus, the majority of the patients of HU group of our series was not controlled.Hyperuricemia can make the bed of a resistant $\mathrm{HTN}$, as reported by Alberto Mazza in Italy [9] where a rate of $63.6 \%$ of resistant HTN was noted among patients with hyperuricemia.

\section{Conclusion}

This preliminary study showed that the hyperuricemia is a frequent comorbidity 
during arterial hypertension and occurs in a pluri-metabolic context.The overweight/obesity, the metabolic syndrome, the use of diuretics, the regulation of the quadritherapy and uncontrolled blood pressure were more frequently found among patients presenting a hyperuricemia in comparison to the normouricemic group. If hyperuricemia has an obvious negative impact on the blood pressure control, however, studies on a large scale seem necessary to determine the benefit of a significant reduction of uric acid rate during the management of arterial hypertension.

\section{Conflicts of Interest}

The authors declare no conflicts of interest regarding the publication of this paper.

\section{References}

[1] Lawes, C.M., Vander Hoorn, S. and Rodgers, A. (2008) International Society of Hypertension. Global Burden of Blood-Pressure-Related Disease. Journal of Hypertension, 371, 1513-1518.

[2] Kearney, P.M., Whelton, M., Raynolds, K., Muntner, P., Whelton, P.K. and He, J. (2005) Global Burden of Hypertension: Analysis of Worldwide Data. Lancet, 365, 217-223. https://doi.org/10.1016/S0140-6736(05)70151-3

[3] Perticone, M., Tripepi, G., Maio, R., Cimellaro, A., Addesi, D., Baggetta, R., et al. (2017) Risk Reclassificaion Ability of Uric Acid for Cardiovascular Outcomes in Essential Hypertension. International Journal of Cardiology, 243, 473-478. https://doi.org/10.1016/j.ijcard.2017.05.051

[4] Sharaf El Din, U.A.A., Salem, M.M. and Abdulazim, D.O. (2017) Uric Acid in the Pathogenesis of Metabolic, Renal, and Cardiovascular Diseases: A Review. Journal of Advanced Research, 8, 551-554. https://doi.org/10.1016/j.jare.2016.11.004

[5] Verdecchia, P., Schillaci, G., Reboldi, G., Santeusanio, F., Porcellati, C. and Brunetti, P. (2000) Relation between Serum Uric Acid and Risk of Cardiovascular Disease in Essential Hypertension.The PIUMA Study. Hypertension, 36, 1072-1078. https://doi.org/10.1161/01.HYP.36.6.1072

[6] Deléaval, P. and Burnier, M. (2005) L'hyperuricémie dans l'hypertension artérielle: Quelle implication ? Revue Médicale Suisse, 1, 2072-2074.

[7] Alderman, M., Cohen, H., Madhavan, S. and Kivlighn, S. (1999) Serum Uric Acid and Cardiovascular Events in Successfully Treated Hypertensive Patients. Hypertension, 34, 144-150. https://doi.org/10.1161/01.HYP.34.1.144

[8] Ueno, S., Hamada, T., Taniguchi, S., Ohtani, N., Miyazaki, S., Mizuta, E., et al. (2016) Effect of Antihypertensive Drugs on Uric Acid Metabolism in Patients with Hypertension: Cross-Sectional Cohort Study. Drug Research, 66, 628-632. https://doi.org/10.1055/s-0042-113183

[9] Mazza, A., Lenti, S., Schiavon, L., Monte, A.D., Townsend, D.M., Ramazzina, E., et al. (2017) Asymptomatic Hyperuricemia Is a Strong Risk Factor for Resistant Hypertension in Elderly Subjects from General Population. Biomed Pharmacother, 86, 590-594. https://doi.org/10.1016/j.biopha.2016.11.104

[10] Ikama, M.S., Nsitou, B.M., Loumouamou, M., Kimbally-Kaky, G. and Nkoua, J.L. (2013) L'observance médicamenteuse et ses facteurs dans un groupe d'hypertendus congolais. Pan African Medical Journal, 15, 121. 
https://doi.org/10.11604/pamj.2013.15.121.2435

[11] Ikama, M.S., Nsitou, B.M., Makani, J. and Nkalla-Lambi, M. (2015) Hypertension artérielle et niveau de contrôle à Brazzaville (Congo): Place du Holter tensionnel. Annales de Cardiologie et D'Angeiologie, 64, 76-80. https://doi.org/10.1016/j.ancard.2015.01.007

[12] Deuxième enquête congolaise auprès des ménages pour le suivi et l'évaluation de la pauvreté (ECOM 2011). Ministère du plan et de l'intégration. Rapport du volet QUIBB-ECOM2 2012, No. 1, 142.

[13] Zimmet, P., Magliano, D., Matsuzawa, Y., Alberti, G. and Shaw, J. (2005) The Metabolic Syndrome: A Global Public Health Problem and a New Definition. Journal of Atherosclerosis and Thrombosis, 12, 295-300. https://doi.org/10.5551/jat.12.295

[14] Kamdem, F., Doualla, M.S., KemtaLekpa, F., Temfack, E., Ngo Nouga, Y., Sontsa Donfack, O., et al. (2016) Prevalence and Factors Associated with Hyperuricaemia in Newly Diagnosed and Untreated Hypertensives in a Sub-Saharan African Setting. Archives of Cardiovascular Diseases, 109, 527-532. https://doi.org/10.1016/j.acvd.2016.02.009

[15] Poudel, B., Yadav, B., Kumar, A., Jha, B. and Raut, K. (2014) Serum Uric Acid Level in Newly Diagnosed Essential Hypertension in a Nepalese Population: A Hospital Based Cross Sectional Study. Asian Pacific Journal of Tropical Biomedicine, 4, 59-64. https://doi.org/10.1016/S2221-1691(14)60209-4

[16] Moulin, S.R., Baldo, M.P., Souza, J.B., Luchi, W.M., Capingana, D.P., Magalhães, P., et al. (2017) Distribution of Serum Uric Acid in Black Africans and Its Association with Cardiovascular Risk Factors. Journal of Clinical Hypertension, 19, 45-50. https://doi.org/10.1111/jch.12863

[17] Diouf, N., Boye, O., Saware, E., Lo, G., et al. (2013) Prévalence de l'hyperuricémie dans la population sénégalaise. Médecine d Afrique Noire Électronique, 60, 437-340.

[18] Fan, X.H., Sun, K., Wang, Y.B., Dang, A.M., Zhou, X.L., Zhang, H.M., et al. (2009) Prevalence and Associated Risk Factors of Hyperuricemia in Rural Hypertensive Patients. National Medical Journal of China, 89, 2667-2670.

[19] Mrug, S., Mrug, M., Morris, A.M., Reynolds, N., Patel, A., Hill, D.C., et al. (2017) Uric Acid Excretion Predicts Increased Blood Pressure among American Adolescents of African Descent. American Journal of the Medical Sciences, 353, 336-341. https://doi.org/10.1016/j.amjms.2017.01.008

[20] Conen, D., Wietlisbach, V., Bovet, P., Shamlaye, C., Riesen, W., Paccaud, F., et al. (2004) Prevalence of Hyperuricemia and Relation of Serum Uric Acid with Cardiovascular Risk Factors in A Developing Country. BMC Public Health, 4, 9. https://doi.org/10.1186/1471-2458-4-9

[21] Banu, I., Nguyen Minh, T., Cosson, E. and Valensi, P. (2017) Rôle de l'hyperuricémie dans la dysfonction autonome cardiovasculaire et l'hypertension artérielle chez les patients obèses. Diabetology \& Metabolic Syndrome, 43, 51.

[22] Moustafa, M. and Owonayo, O. (2000) Facteurs de risque de la goutte chez des patients togolais. Revue du Rhumatisme, 67, 621-626. https://doi.org/10.1016/S1169-8330(00)00017-X

[23] Nganga, N.M., Longo-Mbenza, B., Mumba, N.D., Buassa-Bu-Tshumbu, B., et al. (2016) Hyperuricémie, groupes sanguins et autres facteurs de risque cardiovasculaire en milieuhospitalier de Kinshasa. Journal of Innovation \& Research in Health Sciences and Biotechnology, 1, 113-124.

[24] Johnson, R.J., Perez-Pozo, S.E., Sautin, Y.Y., Manitius, J., Sanchez-Lozada, L.G., 
Feig, D.I., et al. (2009) Hypothesis: Could Excessive Fructose Intake and Uric Acid Cause Type 2 Diabetes? Endocrine Reviews, 30, 96-116. https://doi.org/10.1210/er.2008-0033

[25] Chales, G. and Guggenbuhl, P. (2005) Hyperuricémies, une équation extra-articulaireà trois composantes: rénale, cardiovasculaire et métabolique. La Lettre du Rhumatologue, $314,18-23$.

[26] Bardin, T. and Cohen-Solal, A. (2011) Goutte et pathologies cardiovasculaires. Revue du Rhumatisme, 78, 129-133. https://doi.org/10.1016/S1169-8330(11)70025-4

[27] Zhu, P., Lin, F., Lin, C., Hong, D., Lin, K. and Chen, H. (2012) Effect of Hyperuricemia on the Blood Pressure Response to Antihypertensive Agents in Hospitalized Elderly Patients. Journal of Cardiovascular Medicine, 13, 741-746. https://doi.org/10.2459/JCM.0b013e328358527c

[28] Borghi, C., Tubach, F., De Backer, G., Dallongeville, J., Guallar, E., Medina, J., et al. (2016) Lack of Control of Hypertension in Primary Cardiovascular Disease Prevention in Europe: Results from the EURIKA Study. International Journal of Cardiology, 218, 83-88. https://doi.org/10.1016/j.ijcard.2016.05.044

[29] Dzudie, A., Rayner, B., Ojji, D., Schutte, A.E., Twagirumukiza, M., Damasceno, A., et al. (2017) Roadmap to Achieve 25\% Hypertension Control in Africa by 2025. Cardiovascular Journal of Africa, 28, 262-272. https://doi.org/10.5830/CVJA-2017-040

[30] Cicero, A.F., Salvi, P., D’Addato, S., Rosticci, M., Borghi, C. and Brisighella Heart Study Group (2014) Association between Serum Uric Acid, Hypertension, Vascular Stiffness and Subclinical Atherosclerosis: Data from the Brisighella Heart Study. Journal of Hypertension, 32, 57-64. https://doi.org/10.1097/HJH.0b013e328365b916

[31] Wu, L., He, Y., Jiang, B., Liu, M., Wang, J., Zhang, D., et al. (2017) Association between Serum Uric Acid Level and Hypertension in a Chinese Elderly Rural Population. Clinical and Experimental Hypertension, 39, 505-512. https://doi.org/10.1080/10641963.2016.1259325

[32] Yokokawa, H., Fukuda, H., Suzuki, A., Fujibayashi, K., Naito, T., Uehara, Y., et al. (2016) Association between Serum Uric Acid Levels/Hyperuricemia and Hypertension among 85,286 Japanese Workers. Journal of Clinical Hypertension, 18, 53-59. https://doi.org/10.1111/jch.12627

[33] Cho, J., Kim, C., Kang, D.R. and Park, J.B. (2016) Hyperuricemia and Uncontrolled Hypertension in Treated Hypertensive Patients: K-MetS Study. Medicine, 95, e4177. https://doi.org/10.1097/MD.0000000000004177 